\title{
CONTROLLED FLIGHT INTO STALL (CFIS): FUNCTIONAL COMPLEXITY FAILURES AND AUTOMATION SURPRISES
}

\author{
Lance Sherry, George Mason University, Fairfax, Virginia \\ Robert Mauro, University of Oregon, Eugene, Oregon
}

\begin{abstract}
Nineteen Loss of Control (LOC) accidents resulting in aerodynamic stalls, all involving modern airliners, were analyzed. These accidents were found to be characterized by a structurally and mechanically sound aircraft decelerating through the $1.3 \mathrm{~V}_{\text {Stall }}$ buffer to the stall airspeed - i.e. a Controlled Flight into Stall (CFIS). The accidents occurred during deceleration to the minimum speed envelope (i.e. $1.3 \mathrm{~V}_{\text {Stall }}$ ) under conditions in which the design of the "flightdeck system" requires the flight crew to monitor and intervene to close the gap between automation functions certified to a $10^{-5}$ reliability and a scenario requiring $10^{-9}$ reliability. The analysis yielded three main observations: First, the accidents were the result of a complex sequence of behaviors of the automation functions. There was, however, no consistent failure type in the triggering events (e.g. sensor failures), the effects of the triggering events on the automation (e.g. mode change), or the commands issued by the automation (e.g. thrust setting). Second, the fail-safe element of the "flightdeck system,' the flight crew, were not able to intervene effectively (due to the absence of salient cues to monitor these rare "functional complexity" failures or their effects). Third, there was no one-size-fits-all intervention for these accidents. The stall scenarios required a range of intervention actions that were not clearly cued, preventing the flight crew from determining the appropriate intervention strategy. The implications of these findings for flightdeck procedures, training and automation design are discussed.
\end{abstract}

\section{INTRODUCTION}

The modern airliner accident rate of $10^{-13}$ (IATA, 2013), which is four orders of magnitude smaller than the regulatory $10^{-9}$ target level of safety (ICAO, 2013), is a testament to the operators, designers and regulators of this transportation system. The low accident rate is also a product of the meticulous aviation "safety system" that is the envy of other domains (Bayuk, 2008).

All aviation accidents and incidents are rigorously investigated by safety agencies (Wells, 2004) that seek to prevent recurrence of the same accidents. The accident investigations identify "probable causes" and "contributing factors" that lead to accidents and incidents including: failed aircraft components, failed equipment, problems with procedures, poor training, and even gaps in regulatory requirements. These issues are translated into safety recommendations that can lead to regulatory mandates and/or industry voluntary actions.

In addition to the root cause analysis in the accident investigations, investigators and researchers have sought to identify patterns of causes across accidents from several different crosscutting perspectives. Accidents have been grouped into categories using accident taxonomies such as the CAST/ICAO Common Taxonomy (ICAO, 2006) enabling researchers to look for common causes within each category. For example, Evans, (2007), Lambregts (2008), and Jacobson et.al. (2010) have examined the causes of Loss of Control (LOC) accidents. Researchers also have investigated accident and pilot reports based on the source of error such as unreliable airspeeds (Fucke et al, 2012; Silva et. al. 2012), problems with procedures such as the Go Around procedure (BEA, 2013a), the role of automation errors (e.g. Sarter, Woods and Billings, 1997), and the role of operator errors (e.g. Endsley, 1996; Wickens et al, 2009).

As technology, procedures, training, maintenance, and safety regulations have evolved, many of the "low hanging" accident causes and cross-cutting safety issues have been addressed. As a consequence, the remaining safety issues that now exist lie in the tail of the accident-causes distribution. These accidents are characterized by rare events with complex interrelations among the causes. For example, one of the main findings of a study that 
examined Loss of Control (LOC) accidents found that modern airline accidents are the result of " $a$ range of causal and contributing factors acting in combination" and that "no single intervention strategy ... has emerged" to holistically mitigate these events (e.g. Belcastro \& Foster, 2010, pg 3637).

This paper describes an analysis of a subset of 19 LOC accidents each of which culminated in an aerodynamic stall. The scenarios that led to these rare and complex accidents were examined with the focus on understanding the sequence of events, rather than attempting to determine the failure that may have caused the accident. This analysis led to the following primary conclusions:

- In all of these accidents, a mechanically and structurally sound aircraft was flown into the aerodynamic stall. - controlled flight into stall.

- The triggering events were numerous and varied. The underlying cause was the functional complexity of the aircraft systems and the complexity of the system architecture that allowed a triggering event to affect the automation mode/targets/commands leading to an inappropriate command.

- The main fail-safe element of the "flight deck system," the flight crew, were not able to intervene in a meaningful way for these rare events during time-sensitive critical phases of flight. Further, the flight deck automation lacks reliable salient cues to effectively monitor the automation for events that are obscured by the functional complexity of the system.

- There was a range of appropriate intervention actions depending on the scenario. Further, the flight deck automation lacks salient cues to assist the flight crew in diagnosing the situation and determining the appropriate response from the range of options.

Critical commercial airliner systems required for "safe flight and landing" (i.e. flight control stability augmentation functions, inner-loop flight control, and autoland) are designed to have less than 1 failure in $10^{9}$ operations. For functions that are not required for safe flight or landing but are an integral part of flight management (such as the autothrottle, outer-loop autopilot and flight management functions), the design standard is for less than 1 failure in $10^{5}$ operations. Implicit in this "flight deck system" design is the "intervention function," implemented by the flight crew, that is required to close the gap between automation designed to a reliability standard of $10^{-5}$ and the target level of safety of $10^{-9}$. In the CFIS accidents examined in this study, the flight crew failed to close the gap.

This paper is organized as follows: the next section provides an overview of aerodynamic stalls. This is followed by a section that describes the CFIS accident criteria and a section that describes the results of the analysis. The implications of these results for future work are discussed in the conclusions section.

\section{AERODYNAMICS AND STALLS}

The fundamental phenomenon that enables heavier-than-air flight is that the airflow over an airfoil pushed through the air will generate a Lift force sufficient to raise the airfoil and an additional attached structure (see Figure 1). The properties of the Lift force require a minimum airspeed and cannot exceed a maximum angle-of-attack (i.e. the angle between the airfoil and the oncoming air flow). In the absence of sufficient airflow over the sings, or with too high an angle-of-attack, the airfoil will abruptly cease generating Lift. This condition is known as an aerodynamic stall.

Combinations of aircraft Flight Path Angle (FPA) and Thrust (T) determine the Airspeed (V) of the aircraft. The speed envelope bounds the energy state of the aircraft and defines the minimum airspeed at which the airfoil will generate Lift, the maximum speed for which the aircraft structure is built, and the limits imposed by minimum (i.e. Idle) and maximum Thrust. The minimum speed is the Stall speed $\left(\mathrm{V}_{\text {Stall }}\right)$. This speed depends on the configuration of flaps, slats and landing gear, as well as the bank angle, and the presence of ice on the wings. 


\section{Lift $=1 / 2 \cdot \underline{C_{L}} \cdot$ Air Density $\cdot$ True Airspeed ${ }^{2} \cdot$ \\ Wing Surface Area}

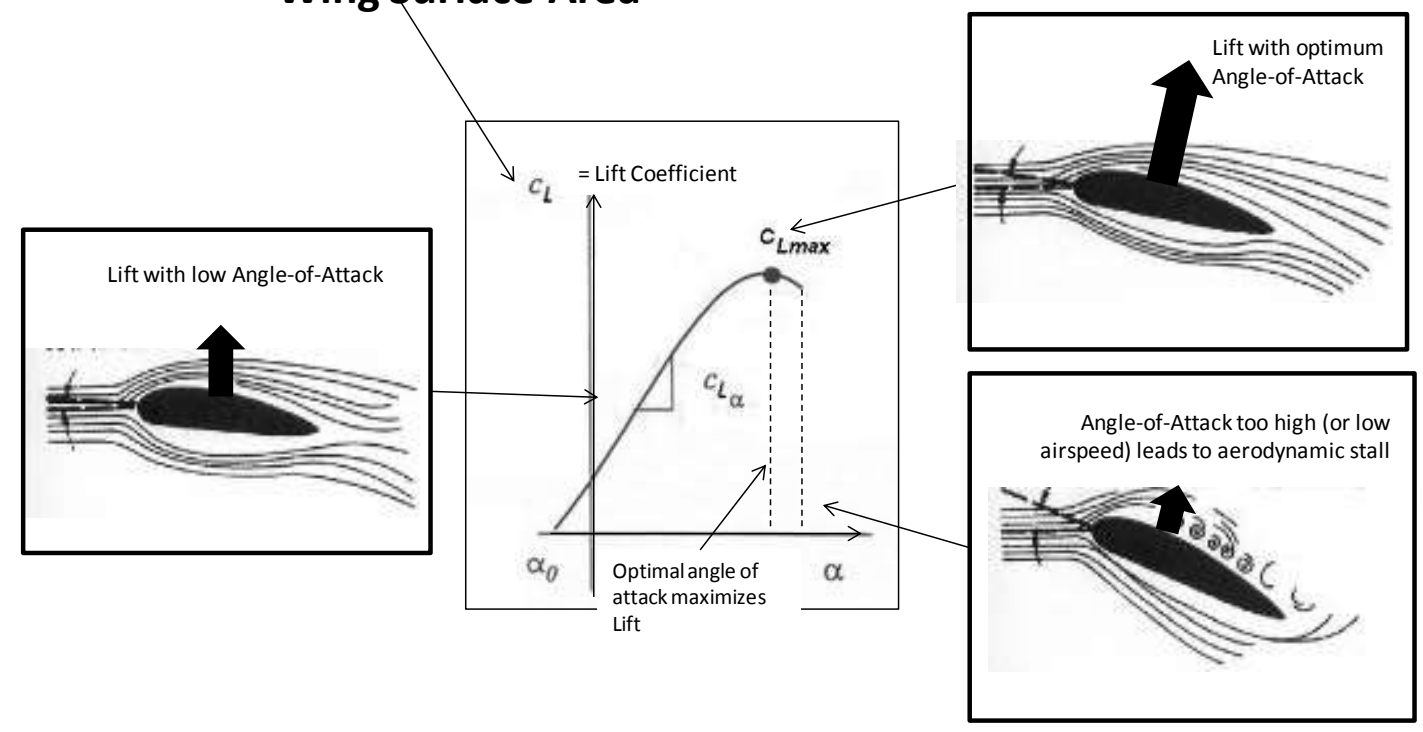

Figure 1: An airfoil generates a Lift force when the airflow over the wing exceeds a minimum airspeed, and when the airfoil angle with respect to the oncoming flow (known as angle-of-attack) is below a maximum allowable angle. The Lift force is proportional to the Lift Coefficient $\left(C_{L}\right)$ that increases with Angle-of-Attack up to a maximum, at which point the airfoil experiences aerodynamic stall.

To ensure that the aircraft does not approach an unsafe energy-state, a buffer is defined within the speed envelope. By convention, the buffer for the stall speed is $30 \%$ of the stall speed $\left(1.3 \mathrm{~V}_{\text {Stall }}\right)$. This serves as the lower limit for speed targets.

$\mathrm{V}_{\text {Stall }}$ and the associated $1.3 \mathrm{~V}_{\text {Stall }}$ are computed by the automation and displayed on the Primary Flight Display (PFD) airspeed tape (Figure 2). The red bar shows $\mathrm{V}_{\text {Stall, }}$ the yellow bar shows the 1.3 $\mathrm{V}_{\text {Stall }}$.

The physics of flight do not prevent an aircraft from decelerating through $1.3 \mathrm{~V}_{\text {Stall }}$ to $\mathrm{V}_{\text {Stall }}$. As a result of the natural aerodynamics it is possible for the FPA and T to be configured, either by manual control or by the automation, such that the aircraft stalls. This paper describes accident scenarios in which these type of stall conditions occur.

\section{CFIS ACCIDENT CRITERIA}

Official accident reports (e.g. NTSB, 2013; NTSB, 2013a; BEA, 2013; ICAO, 2013; ALPA 2005; BEA 2012; NTSB, 2010, DOT AAIA, 2009; NTSB 2006; Flight Safety Foundation, 1999), and industry airline safety data-bases (e.g. ASN, 2013) were searched to identify airline operations (Part 121) and air taxi operations (Part 135) in which aircraft transitioned from safe energy-states within the safe operating speed envelope to an energy-state outside of the safe operating speed envelope by decelerating through $1.3 \mathrm{~V}_{\text {Stall }}$ and $\mathrm{V}_{\text {Stall }}$. Accidents in the takeoff phase in which the aircraft did not accelerate enough to achieve a safe lift generating airspeed are not considered controlled flight into stall because a safe flying speed was never achieved. Such takeoff accidents and incidents are not included in these analyses. The accident scenarios were identified directly from the accident reports.

\section{ANALYSIS}

Nineteen accidents were reviewed. A list and summary of the accidents and their characteristics is included in Sherry et. al. (2013).

\section{Sequence of Events}

All 19 accidents and incidents can be described by the sequence of events presented in Figure 3. The sequence starts with a triggering event (e.g. sensor failure) that has an effect on the automation (e.g. 


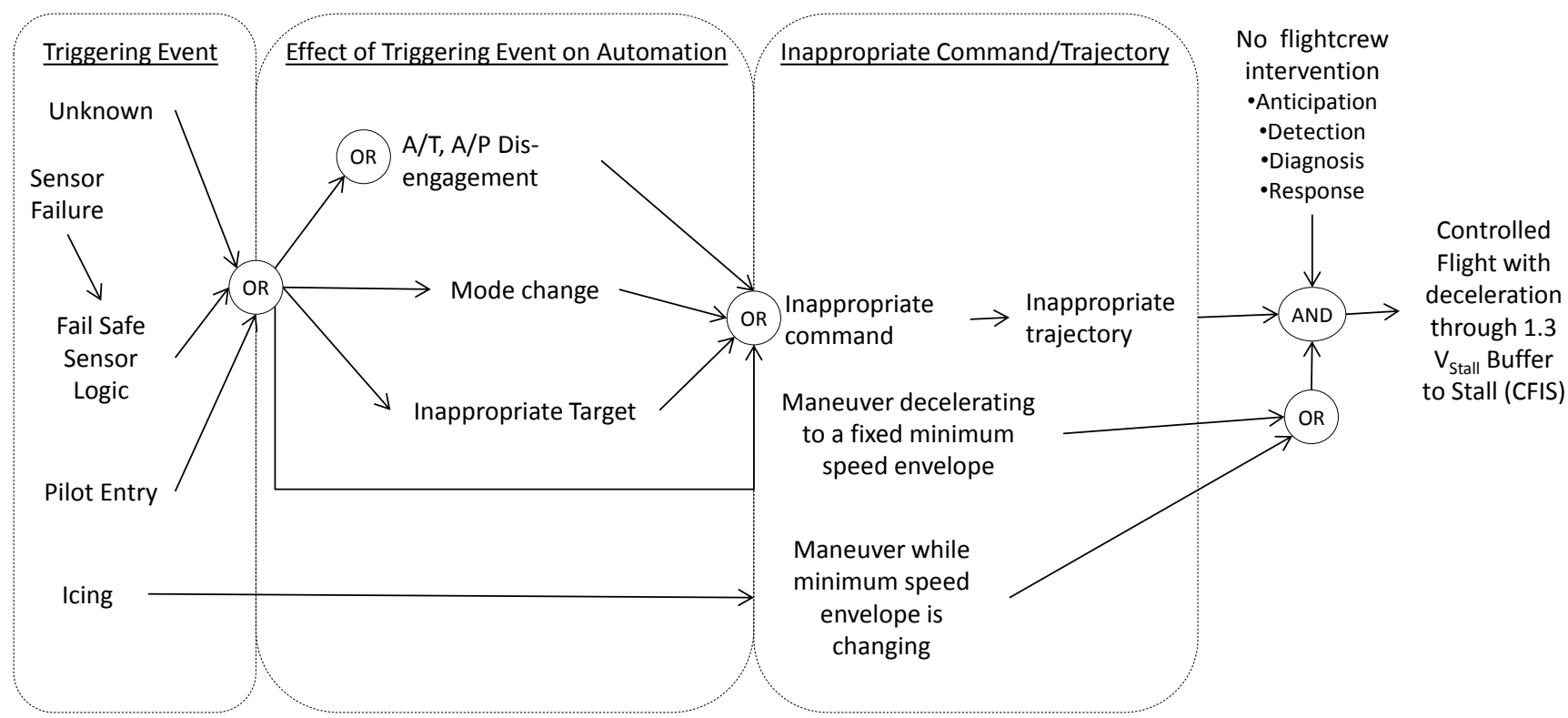

Figure 3: Summary of the scenarios leading to CFIS. A triggering event (e.g. sensor failure or pilot entry) affects the automation engagement status, mode, or target. These changes result in a pitch or thrust command inappropriate for the current operation. When the aircraft is decelerating to 1.3VStall (or the stall speed changes) due to an inappropriate command, the flight crew is unable to intervene in a timely manner.

mode change). This leads to an inappropriate command for pitch or thrust. The inappropriate command occurs while the aircraft is experiencing a relative deceleration to the minimum safe operating speed. The relative deceleration is the result of either the aircraft decelerating to a fixed minimum safe operating speed or a change in the minimum safe operating speed (i.e. ice). Finally, the flight crew does not intervene to arrest the deceleration through the minimum safe operating speed for controlled flight into a stall.

The incidents included here can be described using the following characteristics:

(1) Operational procedure or maneuver

(2) Triggering event

(3) Effect of the triggering event on the automation

(4) Commands and Trajectories

(5) Appropriate intervention response

\section{Operational Procedure or Maneuver}

The CFIS events occurred in all phases of flight (Table 1). The climb phase included 6 accidents. The cruise phase included one accident, the descent phase included 2 accidents and the approach phase included 9 accidents.

Table 1: CFIS accidents and incidents by aircraft state and phase of flight.

\begin{tabular}{|c|c|c|}
\hline $\begin{array}{c}\text { Phase of } \\
\text { Flight }\end{array}$ & Aircraft State & Cases \\
\hline Climb & $\begin{array}{l}\text { Climbing to cleared } \\
\text { altitude }\end{array}$ & $\begin{array}{l}\text { Midwest 490, Provincial } \\
\text { Airlines, Iceland Air } \\
\text { American eagle } 3008 \\
\text { BirgenAir } 301 \text {. NWA } \\
6231\end{array}$ \\
\hline Cruise & $\begin{array}{ll}\text { High altitude flight in } \\
\text { which the } & \text { margin } \\
\text { between Mmo } & \\
\text { and Vs is small } & \\
\text { and }\end{array}$ & Air France 447 \\
\hline Descent & $\begin{array}{l}\text { Decelerating to } \operatorname{Max} \\
\text { Endurance speeds (e.g. } \\
\text { for cruise or for holding) }\end{array}$ & $\begin{array}{l}\text { AAL } 903 \\
\text { XL Germany 888T }\end{array}$ \\
\hline Approach & $\begin{array}{l}\text { Decelerating to approach } \\
\text { speeds at } 1.3 \text { V Stall }\end{array}$ & $\begin{array}{l}\text { Asiana Air, Colgan } \\
\text { EWR/BTV, Colgan Air } \\
\text { 3407, Turkish Airlines } \\
\text { 1951, ThomsonFly } \\
\text { Belfast, ThompsonFly - } \\
\text { B, ThomsonFly- no loc, } \\
\text { King Air Eveleth, United } \\
\text { Express } 629\end{array}$ \\
\hline
\end{tabular}


The climb phase flights were climbing to the cleared altitude with maximum thrust. In the Midwest 490 case, the flight crew had selected a fixed rate-ofclimb at which the airspeed could not be maintained even with the maximum thrust setting. In all the other cases, errors in airspeed resulted in inappropriate commands.

The accidents that occurred during cruise involved sensor failures that could not be handled by the automation. The automation disengaged, transferring control of the flight trajectory to the flight crew. However, the flight crew was faced with the same inaccurate sensor data that caused the transfer of control and failed to regain control of the aircraft.

All the descent and approach cases involved level flight or fixed rate of descent in which the thrust setting was too low to maintain the desired airspeed (e.g. XL Germany 888T, Colgan Air 3407) or the autothrottle was disengaged and no longer controlling airspeed (e.g. AAL 903) or a mode change occurred to a mode that no longer actively controlled to the target airspeed (Asiana Air 214, TA 1951).

\section{Triggering Events}

Analysis of the precursor events that triggered the accident scenarios can be classified into the following categories:

(1) Sensor failures and failures in the associated failsafe sensor failure logic

(2) Changes in the aerodynamics of the aircraft (i.e. ice formation on wings)

(3) Flight crew entries

(4) Unknown events

Sensor failures and failures in the associated sensor fail-safe logic were the most common triggering event. However, there was no single sensor-type or class of failure that was common to all of these cases. Sensors that experienced failures included: angle-of-attack sensors (XL Germany), pitot tubes (AF 447, Midwest 490, BirgenAir 301, NWA 6231), and radio altimeters (e.g. TA 1951). Further, the fail-safe sensor logic included both voting mechanisms that select the perceived nonfailed sensor, as well averaging mechanisms that average sensor inputs.
Changes in aerodynamic characteristics of the aircraft were the result of icing conditions (Colgan Air EWR/BTV, Midwest 490, American Eagle 3008).

Flight crew errors include Aisiana Air Flight 214 in which the flight crew inappropriately selected Flight Level Change (FLCH) mode during the approach (NTSB, 2013b). The selection of FLCH resulted in a change to a "dormant" autothrottle mode in which the autothrottle no longer controlled to the airspeed target.

In some cases the triggering event was not identified (e.g. AAL 903, ThomsonFly Bournemouth, ThompsonFly Belfast, KingAir Evereth,).

Table 2: CFIS accidents and incidents by categories of triggering events.

\begin{tabular}{|l|l|}
\hline Category of Triggering Event & \multicolumn{1}{|c|}{ Cases } \\
\hline $\begin{array}{l}\text { Sensor failures and failures in } \\
\text { the associated fail-safe sensor } \\
\text { failure logic }\end{array}$ & Radio Altimeter: TA 1951, \\
\cline { 2 - 2 } & $\begin{array}{l}\text { Angle-of-Attack Sensors: XL } \\
\text { Germany }\end{array}$ \\
\cline { 2 - 2 } & $\begin{array}{l}\text { Pitot Tubes: AF 447, Midwest } \\
\text { 490, Provincial Airlines, Iceland } \\
\text { Air, BirgenAir 301, NWA 6231 }\end{array}$ \\
\hline $\begin{array}{l}\text { Changes in the aerodynamics } \\
\text { of the aircraft }\end{array}$ & $\begin{array}{l}\text { Colgan Air EWR/BTV, Midwest } \\
\text { 490, American Eagle 3008 }\end{array}$ \\
\hline Flightcrew entry & $\begin{array}{l}\text { Omission: Colgan Air } \\
\text { EWR/BTV, Colgan Air 3407, } \\
\text { United Express 629, KingAir } \\
\text { Evereth; } \\
\text { Commision: Asiana Air 214, } \\
\text { Provincial Airlines }\end{array}$ \\
\hline Unknown events & $\begin{array}{l}\text { AAL 903, ThomsonFly } \\
\text { Bournemouth; ThompsonFly } \\
\text { Belfast; ThomsonFly, location } \\
\text { not specified }\end{array}$ \\
\hline
\end{tabular}

\section{Effects of Triggering Events on the Automation}

The triggering events had a variety of effects on the automation (Table 3). When the triggering event was a sensor failure there were four types of effects on the automation:

(1) Automation was disengaged (e.g. Air France 447)

(2) Automation mode was changed (e.g. Turkish Airlines 1951)

(3) Target used for control was calculated incorrectly (XL German T888) 
Table 3: CFIS accidents and incidents by category of triggering event and effects of triggering events on the automation.

\begin{tabular}{|c|c|c|}
\hline $\begin{array}{l}\text { Category of } \\
\text { Triggering } \\
\text { Events }\end{array}$ & $\begin{array}{l}\text { Effects of } \\
\text { Triggering } \\
\text { Events on } \\
\text { Automation } \\
\end{array}$ & $\begin{array}{l}\text { CFIS } \\
\text { Accidents/Incidents }\end{array}$ \\
\hline \multirow[t]{4}{*}{$\begin{array}{l}\text { Sensor } \\
\text { failures and } \\
\text { associated } \\
\text { fail-safe } \\
\text { sensor failure } \\
\text { logic }\end{array}$} & Disengagement & $\begin{array}{l}\text { AF } 447 \\
\text { Provincial Airlines } \\
\text { Midwest } 490 \\
\text { AAL } 903 \\
\text { Air France } 447\end{array}$ \\
\hline & $\begin{array}{l}\text { Mode change } \\
\text { (A/T) } \\
\text { Moded-Input } \\
\text { Device mode } \\
\text { change } \\
\text { (Throttle } \\
\text { Levers) }\end{array}$ & $\begin{array}{l}\text { Asiana Air } 214 \\
\text { TA 1951, }\end{array}$ \\
\hline & Target error & XL Germany \\
\hline & Command error & $\begin{array}{l}\text { Iceland Air } 662 \\
\text { Midwest } 490 \\
\text { Provincial Airlines } \\
\text { BirgenAir } 301 \\
\text { NWA } 6231 \\
\end{array}$ \\
\hline $\begin{array}{l}\text { Changes in } \\
\text { the } \\
\text { aerodynamics } \\
\text { of the aircraft }\end{array}$ & $\begin{array}{l}\text { Stall speed } \\
\text { calculation }\end{array}$ & $\begin{array}{l}\text { Colgan Air/EWR-BTV } \\
\text { American Eagle } 3008\end{array}$ \\
\hline \multirow[t]{2}{*}{$\begin{array}{l}\text { Flightcrew } \\
\text { entry }\end{array}$} & & $\begin{array}{l}\text { Omission: Colgan Air } \\
\text { EWR/BTV, Colgan Air } \\
\text { 3407, United Express } \\
629 \text {,; King Air Eveleth }\end{array}$ \\
\hline & & Commision: \\
\hline $\begin{array}{l}\text { Unknown } \\
\text { events }\end{array}$ & & $\begin{array}{l}\text { AAL } 903 \\
\text { ThomsonFly } \\
\text { Bournemouth } \\
\text { ThompsonFly Belfast } \\
\text { ThomsonFly, } \\
\text { location specified no }\end{array}$ \\
\hline
\end{tabular}

(4) Command for pitch or thrust was inappropriate for the current maneuver (e.g. BirgenAir 301)

\section{Automation Commands and Trajectories}

The effects of the changes on the automation can be grouped into three categories of inappropriate automation commands: (1) inappropriate thrust, (2) inappropriate pitch, (3) and autopilot disengagement. In seven cases, the autothrottle did not acquire the desired airspeed target (e.g. TA 1951). In four cases, the aircraft experienced an unexpected pitch-up that led to airspeed decay (e.g. BirgenAir). In one case, the automation terminated engagement and transferred control of the aircraft to the flight crew (AF 447).

\section{Intervention Response and Response Decision}

Table 4: CFIS accidents and incidents by type of effect of triggering event on the automation.

\begin{tabular}{|l|l|}
\hline $\begin{array}{c}\text { Type of effect of triggering } \\
\text { event on the automation }\end{array}$ & \multicolumn{1}{|c|}{ CFIS Accidents/Incidents } \\
\hline Thrust advance anomaly & $\begin{array}{l}\text { Asiana Air 214 } \\
\text { TA 1951 } \\
\text { AAL 903 } \\
\text { ThomsonFly Bournemouth } \\
\text { ThompsonFly Belfast } \\
\text { ThomsonFly, location not } \\
\text { specified } \\
\text { XL Germany }\end{array}$ \\
\hline Pitch anomaly & $\begin{array}{l}\text { Midwest 490 } \\
\text { Iceland Air 662 } \\
\text { Birgen Air 301 } \\
\text { NWA 6231 }\end{array}$ \\
\hline Autopilot Disengagement & AF 447 \\
\hline
\end{tabular}

Analysis of the accidents showed that there was no single flight crew response to the events that led to the CFIS accidents that would have been appropriate in all cases. There were a variety of correct responses. These responses can be categorized by the required change in flight crew actions and the appropriate degree of automation to use in the maneuver (see Table 5).

In several accidents such as XL Germay, Midwest 490, Provincial, ThomsonFly-Bournemouth, ThompsonFly - Belfast, and BirgenAir, the accident reports identify interventions in which the recommended procedure is to abort the maneuver being executed and transition to an alternate safe procedure. These interventions include aborting approaches by performing a Go Around (ThomsonFly - Bournemoth, ThomsonFly-Belfast) and terminating a climb or descent to level-off (XL Germany, Midwest 490, Provincial, BirgenAir 301).

In other cases, the accident reports suggest that it would have been possible to continue with the maneuver being executed with a manual over-ride of the auto-flight system (Colgan Air-Burlington, Colgan Air-Buffalo, Turkish Airlines 1951, United Express 629. In other cases (AAL 903), a manual mode/target selection followed by auto-flight system re-engagement would have been appropriate. In hindsight, the lack of airspeed information in two accidents (AF 447 and NWA 6231) predicated aborting the existing procedure and resorting to a "pitch-and-power" maneuver (i.e. wings level, pitch 5 degrees up, power $-75 \%$ thrust). 
TABLE 5: CFIS accidents and incidents by appropriate intervention procedure. Organized by the appropriate intervention degree of automation, and the criteria for selecting the intervention.

\begin{tabular}{|c|c|c|c|}
\hline $\begin{array}{l}\text { Procedure } \\
\text { Status }\end{array}$ & $\begin{array}{l}\text { Degree of } \\
\text { Automation }\end{array}$ & Criteria & CFIS Cases \\
\hline $\begin{array}{l}\text { Continue } \\
\text { Procedure }\end{array}$ & $\begin{array}{l}\text { Manual } \\
\text { mode/target } \\
\text { selection } \\
\text { Re-engage } \\
\text { auto-flight }\end{array}$ & $\begin{array}{l}\text { Confidence in } \\
\text { automation } \\
\text { and flight deck } \\
\text { information } \\
\text { (i.e. sensor } \\
\text { data) }\end{array}$ & $\begin{array}{l}\text { AAL } 903 \\
\text { AsianaAir } 214\end{array}$ \\
\hline $\begin{array}{l}\text { Continue } \\
\text { Procedure }\end{array}$ & $\begin{array}{l}\text { Manual } \\
\text { Override }\end{array}$ & $\begin{array}{l}\text { No confidence } \\
\text { in automation. } \\
\text { Confidence in } \\
\text { flight deck } \\
\text { information } \\
\text { (i.e. sensor } \\
\text { data) }\end{array}$ & $\begin{array}{l}\text { Colgan Air - } \\
\text { Burlington } \\
\text { Colgan Air - } \\
\text { Buffalo } \\
\text { Turkish Airlines } \\
1951 \\
\text { United Express } \\
629\end{array}$ \\
\hline $\begin{array}{l}\text { Abort } \\
\text { Procedure }\end{array}$ & $\begin{array}{l}\text { Manual } \\
\text { mode/target } \\
\text { selection } \\
\text { Re-engage } \\
\text { auto-flight }\end{array}$ & $\begin{array}{l}\text { Confidence in } \\
\text { automation. } \\
\frac{\text { No confidence }}{\text { in flight deck }} \\
\text { information } \\
\text { (i.e. sensor } \\
\text { data) }\end{array}$ & $\begin{array}{l}\text { XL Germany } \\
\text { Midwest } 490 \\
\text { Provincial } \\
\text { ThomsonFly } \\
\text { (2007), } \\
\text { ThomsonFly } \\
\text { (2007a), } \\
\text { Birgen Air } 301\end{array}$ \\
\hline $\begin{array}{l}\text { Abort } \\
\text { Procedure }\end{array}$ & $\begin{array}{l}\text { Manual } \\
\text { Override } \\
\text { (fly pitch and } \\
\text { power) }\end{array}$ & $\begin{array}{l}\text { No confidence } \\
\text { in automation. } \\
\text { No confidence } \\
\text { in flight deck } \\
\text { information } \\
\text { (i.e. sensor } \\
\text { data) }\end{array}$ & $\begin{array}{l}\text { Air France } 447 \\
\text { NWA } 6231\end{array}$ \\
\hline
\end{tabular}

The decision making required to identify the appropriate response frequently was not supported by the available automation cues. This decision must be based in part on the confidence that the flight crew has in the status of: 1) the aircraft structure and airfoils, 2) the aircraft sensors, 3) the control surface and propulsion systems, and 4) the automation. As the events leading to the CFIS accidents unfolded, the degree to which the automation was functioning, the status of the sensors, and the degree to which other aircraft systems may have been degraded would not have been obvious to the flight crew.

The execution of the appropriate intervention response was hindered in some cases by moded input devices that behaved differently under different circumstances. For example, in the aircraft involved in the TA 1951 accident, the throttle levers operate with two modes of operation. In the "airborne mode," the throttle setting can be manually over-ridden and will hold the manually set thrust setting. In the "land mode," the throttle setting can be manually overridden, but the thrust setting will automatically retard to idle unless a pilot holds the throttles in position. In the Asiana 214 accident, preliminary information indicates that the pilot overrode the throttle setting by manually repositioning the throttles, but expected the autothrottle to advance to maintain airspeed. In these aircraft, the state of the autothrottle mode is not directly annunciated on the flight deck.

\section{CONCLUSIONS AND FUTURE WORK}

Studying a series of accidents across domains (i.e. nuclear power plants, aircraft, ships, petrochemical processing plants), sociologist Charles B. Perrow, identified a phenomenon he labeled as "Normal Accidents"(Perrow, 1984). These accidents were characterized by a failure that was the result of the interaction of functions with complex behaviors within a tightly coupled complex system.

Perrow (1984) argued that in complex systems it is inevitable that the system occasionally will yield behavior that is inappropriate in certain circumstances and surprising to operators monitoring the system. For example, the system designers may not have considered particular combinations of input conditions that may occur in unusual circumstances. Alternately the system itself may generate a rare combination of intermediate states that are not covered by the design. These are "functional complexity failures" - there is no physical component malfunction, the automation behaves as it was designed, but the functional complexity results in a failure condition.

In many cases, the surprising behavior of the system cannot be easily detected by the operators. If the situation is detected, the correct intervention is difficult to determine. Perrow describes this situation as an event that both starts a fire and simultaneously deactivates the fire alarm.

\section{Controlled Flight into Stall}

The CFIS accidents described in this paper fit the characteristics of the "Normal Accident." First, a structurally and mechanically sound aircraft is flown into an aerodynamic stall. Second, the source of the 
failure is a combination of complex interactions. Although a deceleration through $1.3 \mathrm{~V}_{\text {Stall }}$ and then through $\mathrm{V}_{\text {Stall }}$ occurred in each accident, there is no pattern or consistent failure in the types of triggering events, in the effects of the triggering events on the automation, or the inappropriate commands. Third, the available information does not reliably provide the flight crew, which is supposed to serve as the "fail-safe" component of the system, with clear cues that could be used to assess the situation and determine the appropriate interventions.

\section{Flight Crew Intervention}

The concept of operations for the "flight deck system" is for the flight crew to delegate tasks to the automation and monitor its performance. In the event of inappropriate commands (e.g. throttles maintain idle thrust when the crew expects them to advance), the flight crew is expected to intervene.

The reliability of the flight crew to detect the rare events of the accident scenario is compromised by:

- the "hidden" nature of fail-safe sensor logic

- "silent" and/or "masked" automation responses

- the absence of cues to anticipate the speed envelope violation,

- difficulty in recognizing a speed envelope violation due to noise in the airspeed signal

- difficulties in recognizing the airspeed envelope violation due to non-linearity and latency in the thrust response near the idle thrust setting.

In addition to the issues with anticipating and detecting the deceleration through $1.3 \mathrm{~V}_{\text {Stall }}$, determining the appropriate interventions is complicated by:

- the variety of possible responses (from re-engage the auto-flight system or re-select the mode, to abort the procedure, to "aviate" with pitch-andpower)

- the absence of salient and unambiguous cues on the flight deck to provide sufficient information for the flight crew to select the appropriate response.

\section{Mitigation Steps: Fixing the Real Problem}

Because of the great variety of triggering events, it is unlikely that an amelioration strategy based on identifying and eliminating triggering events will yield substantial returns. Potential triggering events are difficult to identify. Once a potential triggering event is identified and an appropriate intervention strategy developed, the result will be a fix for only one of many potential one-of-a-kind problems.

The other alternative is to improve the detection and intervention strategies. The Federal Aviation Administration (FAA) has taken several steps in the area of low airspeed alerting: Amendment to CFR 25-121, 2007 flight guidance (autopilot/autothrottle), and performance and handling qualities in icing conditions to improve transport airplane standards for low airspeed protection Advisory Circular 25-11A was revised to include guidance for low speed awareness, and CFR 25.1322 revised the rule for flight crew alerting. Low Airspeed Awareness FAA A-10-11 recommends that the airspeed indicator depict a yellow/cautionary band above the low airspeed cue or airspeed indicator digits turn from white to yellow/amber as the airspeed approaches the low airspeed cue (AC 25-11A, section 2.3 Electronic Flight Displays). FAA A-10-12 recommends the installation of low airspeed alert systems that provide pilots with redundant aural and visual warnings of an impending low airspeed condition.

In many of the CFIS accidents analyzed here the crew had legitimate operational reasons to decelerate the aircraft to $1.3 \mathrm{~V}_{\text {Stall. }}$ However, after the automation generated an inappropriate command, the flight crew failed to appropriately intervene to arrest the descent and deceleration. Six issues, each of which implies a different possible intervention strategy, emerged from the analysis.

(1) Anticipation and detection of trajectory - provide cues to anticipate (not just detect) the deceleration through $1.3 \mathrm{~V}_{\text {Stall }}$.

(2) Anticipation and detection of triggering events and automation effects - provide cues to identify sensor failures, mode changes, and inappropriate commands

(3) Airspeed Call-outs Procedures - proceduralize the explicit checking of the airspeed via call-outs.

(4) Flight deck cues to explicitly aid in diagnosis and intervention - provide cues to diagnose the 
situation and cue the appropriate intervention strategy

(5) Annunciate when the automation is NOT controlling to the target

(6) Annunciation of integrity of flight deck data

These and other candidate mitigation actions are described in detail in companion papers.

\section{References}

ALPA (2005) Submission of the Air Line Pilots Association to the National Transportation Safety Board Regarding an Upset Event Involving Midwest Airlines Flight 490 Union Star, Missouri, May 12, 2005. Air Line Pilots Association, Int'l, 1625 Massachusetts Ave NW, Washington, DC 20036

Bayuk, A.J. (2008) Aviation Safety Management Systems as a Template For Aligning Safety with Business Strategy in Other Industries. American Society of Safety Engineers - The Business of Safety: A Matter of Success Symposium. Baltimore, Maryland, march 13-14, 2008.

Belcastro, C.M. \& J.V. Foster (2010) Aircraft Loss-of-Control Accident Analysis. AIAA Guidance, Navigation, and Control Conference. 2-5 August 2010, Toronto, Ontario, Canada. pg 3637-3675.

BEA (2013) Bureau d'Enquêtes et d'Analyses pour la sécurité de l'aviation civile. Available 12/23/2013 at http://www.bea.aero/en/

BEA (2013a) Study on Aeroplane State Awareness during Go-Around. Bureau d'Enquêtes et d'Analyses pour la sécurité de l'aviation civile. August, 2013. Available 12/23/2013 at http://www.bea.aero/etudes/asaga/asaga.study.pdf

BEA (2012) Final Report On the accident on 1st June 2009 to the Airbus A330-203 registered FGZCP operated by Air France flight AF 447 Rio de Janeiro - Paris. Bureau d'Enquêtes et d'Analyses pour la sécurité de l'aviation civile. Published July 2012. Available on BEA website on 12/23/13 at http://www.bea.aero/docspa/2009/fcp090601.en/pdf/f-cp090601.en.pdf

Dept. for Transport, Air Accident Investigation Branch (2009) Report on the serious incident to Boeing 737-3Q8, registration G-THOF on approach to Runway 26 Bournemouth Airport, Hampshire on 23 September 2007. Aircraft Accident Report 3/2009.

Endsley, M.R. (1996) Automation and Situation Awareness. In R. Parasuraman \& M. Mouloua (Eds)
Automation and Human Performance: Theory and Applications (pg 163 - 181). Mahwah, N.J.:

Lawrence Erlbaum.

Evans, Joni K., "An Examination of In Flight Loss of Control Events During 1988-2004", Alliant Techsystems, Inc., NASA Langley Research Center, Contract No.: TEAMS:NNL07AM99T/R1C0, Task No. 5.2, 2007.

Flight Safety Foundation (1999) Erroneous Airspeed Indications Cited in Boeing 757 Control Loss. Vol 56, No. 10. October 1999

Fucke, L., R. Nicholson, R. Mumaw (2012) Unreliable Airspeed - Making Valid Assumptions on Flight Crew Performance. 28th International Congress of the Aeronautical Sciences. September 23-28 2012, Brisbane, Australia.

IATA (2013) IATA Safety Report. 49th Edition issued in April 2013. 800 Place Victoria, PO Box 113, Montréal, Quebec, H4Z 1M1

ICAO (2013) 2013 Safety Report. International Civil Aviation Organization, 999 University Street, Montréal, Quebec, Canada, H3C 5H7

ICAO (2006) Adopting CICTT Taxonomies and Standards. Commercial Aviation Safety Team (CAST)/ International Civil Aviation Organization (ICAO) Common Taxonomy Team (CICTT). Available 01/20/14 at http://www.intlaviationstandards.org/Documents/CIC TTTaxonomiesAdoption1.1.pdf

Lambregts, A. A., Nesemeier, G., Wilborn, J. E., and Newman, R. L., "Airplane Upsets: Old Problem, New Issues," AIAA Modeling and Simulation Technologies Conference and Exhibit, 2008, AIAA 2008-6867.

NTSB (2013) National Transportation Safety Board - Aviation Accident Reports. Available on $12 / 24 / 2013$ at http://www.ntsb.gov/investigations/reports_aviation.h $\underline{\mathrm{tml}}$

NTSB (2013b) Flight Data Recorder Factual Report of Group Chairman [for Asiana Airlines 214]. Docket No. SA-537, Exhibit Nos. 10-A, 10-B, 10-C

NTSB (2010) Aircraft Accident Report: Loss of Control on Approach Colgan Air, Inc. Operating as Continental Connection Flight 3407 Bombardier DHC-8-400, N200WQ, Clarence Center, New York, February 12, 2009. National Transportation Safety Board, 490 L'Enfant Plaza S.W., Washington, D.C., 20594. NTSB/AAR-10/01, PB2010-910401, Notation 8090A, Adopted February 2, 2010. 
NTSB (2006) Midwest Airlines Flight 490 Union Star, Missouri, May 12, 2005. Available on NTSB website on $12 / 23 / 13$ at http://www.ntsb.gov/aviationquery/brief2.aspx?ev_id $=20050523$ X00653\&ntsbno $=$ NYC05MA083\&akey $=$ 1

Perrow, C. (1984) "Normal Accidents.” Basic Books, New York.

Sarter, N.B., D.D. Woods, C.E. Billings (1997) Automation Surprises. Handbook of Human Factors $\&$ ergonomics, $2^{\text {nd }}$ Edition, Editor: G. Salvendy. Wiley, 1997.

Silva, S., R. K. Nicholson (2012) Categorization of Unreliable Airspeed Events Using Rasmussen's Human Performance Model. 28th International Congress of the Aeronautical Sciences. September 23-28 2012, Brisbane, Australia.

Wells, A. (1997) Commercial Aviation Safety. McGraw-Hill, New York.

Sherry, L. R. Mauro, I. Barshi \& M. Feary (2014) Mitigating Controlled Flight in Stall Accidents. Internal Report, Center for Air Transportation Systems Research, George Mason University (CATSR-007-2013)

Wells, A. \& C.C. Rodrigues (2004) Commercial Aviation Safety. McGraw-Hill Professional: New York

Wickens, C.D., B.L. Hoeey, B.F. Gore, A. Sebok, C.S. Koenicke (2009) Identifying Black
Swans in NextGen: Predicting Human Performance in Off-Nominal Conditions. The Journal of the Human Factors and Ergonomics Society, Volume 51, pg 638.. Online version of the article available http://hfs.sagepub.com/content/51/5/638

\section{Acknowledgements}

This work was funded in part by NASA NRA NNX12AP14A and internal GMU Research Foundation funds. Thank you for technical suggestions from Immanuel Barshi, Michael Feary, Randy Bailey, Paul Krasa, and Steve Jacklin (NASA), Houda Kourdali, George Dononhue, Akshay Belle, John Shortle, Mike Hieb and Paulo Costa (GMU), and Yong Tian (Beijing University of Aeronautics and Astronautics)

\section{Email Addresses}

Lance Sherry 1sherry@gmu.edu

Robert Mauro mauro@uoregon.edu

2014 Integrated Communications Navigation and Surveillance (ICNS) Conference

April 8-10, 2014 